\title{
Data Driven Marketing Applications for Agriculture Services
}

\author{
Rekha Dabbara*, M. Chandrakumar, V. Anandhi and D. Muruganandhi \\ Warden office, Tamil Nadu Agricultural University, Coimbatore-641003, India \\ *Corresponding author
}

\section{Keywords \\ Agriculture, \\ Produce, Marketing, \\ Digital Marketing, \\ Information \\ communication \\ technology.}

Article Info

Accepted:

20 January 2020

Available Online:

10 February 2020

\section{A B S T R A C T}

Agriculture marketing system has undergone several changes over the last 60 years owing to the increased marketed surplus, increase in urbanization and income levels and consequent changes in the pattern of demand for marketing services; increase in linkages with distant and overseas markets. Use of information and communication technology (ICT) in agricultural sector can be called as e-Agriculture or e-Agribusiness.ICT helps small farm holders to find multiple buyers for producer who are willing to pay high price. Use of mobile application providing price information to farmers can reduce market distortions. In the Global scenario, in Ghana, mfarms provides the tools to help every actor within the agricultural value chain. In Zambia, Madagascar and Zimbabwe, Farmbook app provides farmers with access to a business planning process, that is focused on their product and market opportunity. In China's agricultural industry, traditionally farmers plan their crop based on sales of previous season. Pinduoduo app gave out over 500,000 kilograms of free fruit every day, benefiting not only consumers but also growers in rural areas for playing Duo Duo Orchard game in the app . e-NAM is developed to transport the agri product from one market to another in smooth way to save the produce. e-Choupal links rural farmers via internet for procurement of agriculture and aquaculture products like coffee, soybean, prawns . Mandi trade is a one-step platform for farmers where information about weather updates, crop prices, shop agri based products, selling their produce, agricultural news are all presented in one mobile application. eMandi app platform does not only facilitate connecting, procuring and selling between the right vendors, but also ensures the right transportation options for the best value in the entire transaction. IFFCO iMandi app one stop shop for farmers to buy and sell agri products, allow farmers to buy IFFCO products like fertilizers, seeds at discounted price with free delivery. Mandee App is business to business platform for buying the agriculture products by wholesalers, retailers, traders. This article gives idea about current digital services in marketing of agriculture produce.

\section{Introduction}

India is an agricultural country that depends on agriculture sector directly or indirectly. India laid much emphasis on agriculture production with world ranking of second in rice, fruits, and vegetables after China. Marketing plays eminent role in reach of agriculture produce to consumers, selling of output, fetching good price, creating 
relationships, satisfying customers. Agriculture marketing is inferred to cover services involved in moving an agriculture product from the farm to the target consumer. It helps in planning, organizing, grading, packing, storage, food processing, distribution and advertising. Agriculture marketing system has undergone several changes over the last 60 years owing to the increased marketed surplus, increase in urbanization and income levels and consequent changes in the pattern of demand for marketing services; increase in linkages with distant and overseas markets.

The main objective of agriculture marketing is to reduce the cost of marketing. Agricultural Information Technology is one of the important factors that lead to the expected development. Use of information and communication technology (ICT) in agricultural sector can be called as eagriculture or e-agribusiness. Digitalization will change every part of agri food chain but require major transformations in farming, rural economics, and marketing of produce. The application of ICT in agriculture has positive effects for farmers in terms of accessing market information and promoting agricultural products.

The benefits to farmers by sale of agricultural produce in the regulated market varies from area to area because of the variation in the spread of regulated markets over the regions and the existence of necessary infrastructural amenities/ facilities in these regulated markets (Jairath, M. S,2012).

Information and communication technology(ICT) solution in agriculture marketing helps to evaluate, plan, deploy impactful interventions to facilitate smallholder marketing (USAID FACET project,2012). Retail marketing of agriculture commodities through initiatives made by multinational companies did not attempt to explain how extension services to farmers are linked to information technology(Bihu santosh behera, et al.,).

License for Electronic Spot Exchange has also been granted to National Spot Exchange Ltd (NSEL), NCDEX Spot Exchange Ltd. (NSPOT) and National Agriculture Produce Marketing Committee of India Ltd. (NAPMC) as spot exchange helps to remove intermediatries (Surarchith,N.K. et al., 2013).Agricultural marketing functionaries, marketing of agriculture produce, importance of agriculture produce (Ms.K.Kiruthiga, et al., 2015). Few prominent private sector organizations adopted different models for agricultural Marketing (V.Nagendra .,2015).

Telephone is used as means of communication for marketing of produce in India. Number of mobile enable services is addressing the information needs of the stakeholders to some extent ( Singh,U.S., 2013). Experience and the potential of agribusiness franchising of commodities in India is growing at a rapid extent and the interest among the people for agro startups is more(Sukhpal Singh.,2014). The scope of Indian agriculture marketing systems, major private sector initiatives are reviewed( shakeel-rehman, et al., 2012).

Information and Communication Technology solutions to enhance Agriculture Marketing Current Agricultural marketing system globally are the outcome of several years of Government intervention. In digital world, we can revolutionize agriculture market end to end digitally. ICT helps small farm holders to find multiple buyers for producer who are willing to pay high price. Small holders deal with only handful buyers who either pickup directly from them. Use of mobile application providing price information to farmers can reduce market distortions. In the Global scenario in Kenya, M-Farm mobile applications are enabling collective sales where users can find location of farmers, 
input dealers, buyers, warehouse for storage, credit etc and it reported that farmers are receiving higher prices in market. SMS the number 3555 to get information pertaining to 3 services are retail price of their products, Collective crop selling, Collective input buying.

Private sector initiatives that are successfully disseminating information to the farmers on a daily basis. Duo Duo Orchard game has been incredibly popular since it launched in 2018.In June last year, a month after the game launched, nearly two million new virtual trees were planted every day. Pinduoduo gave out over 500,000 kilograms of free fruit every day, benefiting not only consumers but also growers in rural areas.

Over 11 million daily active users (DAU) log on to the game to water their trees. Pinduoduo app can also predict the demand for fruit, and share this information with growers. With Pinduoduo's large fruit orders directly from rural growers, these growers can sell their fresh produce at a higher price as the additional layers of redistribution are removed.

In Ghana, mfarms provides the tools to help every actor within the agricultural value chain. Mobile application tools are enabling collective sales where users can find location of farmers, input dealers, buyers, warehouse for storage, credit, forecast on trends of price etc and it reported that farmers are receiving higher prices in market.

In Zambia, Madagascar and Zimbabwe, Farmbook app provides farmers with access to a business planning process that is focused on their product and market opportunity. More attention needs is given to monitoring the profits that different types of farmers gain from using technologies and linking to markets.

Technology innovations are increasing efficiency in China's agricultural industry. Traditionally, farmers plan their crop based on sales of previous season. With Alibaba's flash sale and marketing platform 'Juhuasuan' its virtual farming feature "Jutudi" allowing farmers access to consumer sales data so that they can more accurately plan crops based on current consumer trends.

It lets consumers pre order agriculture products before harvest. It directly works with cooperatives and farmers to bypass middlemen. Consumers are enjoying discounts of $30 \%$ to $50 \%$ lower than regular prices.

In India, e-choupal by ITC,AGMARKNET, $M \&$ M, Godrej group, e-NAM etc play a vital role for welfare of farmers

Agricultural products range from staple to high-value crops; however, there is an emphasis on cash crops that are marketed by smallholder producers and provide income to support rural households.

\section{e-Choupal}

It is an initiative by Indian Tobacco Company limited (ITC) in the year 2000. e-Choupal links rural farmers via internet for procurement of agriculture and aquaculture products like coffee, soybean, prawns etc.

ITC will provide computers, internet access in rural area where farmers can directly negotiate price and sale. Farmers obtain information on mandi prices, good farming practices, weather forecast, placing orders for agriculture inputs(seeds, fertilizers).

ITC kiosk is run by sanchalak (a literate and trained farmer). The computer is placed in sanchalaks home and is linked to internet. Each kiosk can serves 600 farmers in surrounding 10 villages within $5 \mathrm{~km}$ radius. It eliminates middlemen completely. Since introduction of e-Choupal services farmers 
have seen raise in their income levels. At present 6435 e-Choupals are in operation over 40,000 villages in 10 states.

\section{Agmarknet}

Agricultural Marketing information network is a sponsored project of Directorate of Marketing and Inspection (DMI) to establish a nationwide information network for speedy collection and diffusion of price, commodities, sales, arrival information, contract farming. It started in march 2000 by union Ministry of Agriculture. It links around 7000 agriculture wholesale markets in India. Portal is in 8 regional languages and English. More than 7000 markets are covered under this with more than 350 commodities.

Kisan Suvidha is an omnibus mobile app developed to help farmers by providing relevant information to them quickly. They can get the information on weather of current day and next 5 days, dealers, market prices, agro advisories, plant protection, IPM Practices etc. AgriMarket mobile app can be used to get the market price of crops in the markets within $50 \mathrm{~km}$ of the device's location. This app automatically captures the location of person using mobile GPS and fetches the market price of crops in markets within the range of $50 \mathrm{~km}$.

\section{e-NAM}

Pan India Electronic trading portal integrating 585 markets across 16 states and 2UTs out of over 2700 APMCs. More than 164.53 lakh tonnes of farm commodities have been transacted on e-NAM. It is developed to transport the agri product from one market to another in smooth way to save the produce.

It is managed by Small Farmers Agribusiness Consortium. NABARD sanctioned Rs 2000 crore for updating infrastructure at APMCs.
The idea of e-NAM came from Rashtriya e Market Services (ReMS) in Karnataka state.

\section{IKisan}

The only entity that is specialized across the agri value chain with specific mandate and capabilities to harness the power of Information Technology. It provides information on market prices, products, weather, management techniques etc.

\section{Agri Trade}

It is a market place mobile application developed to connect farmers and traders across the nation. App enables farmers to sell their agriculture products directly to traders from all locations of India.

\section{Agweb}

Featuring markets, news and weather in the app. It is award winning app. App provide free market quotes from Commodity update, listen to top industry radio shows, including "Agri Talk" and "Market Rally," market quotes, weather updates, market prices and more.

\section{Mandi Trade}

It's a one-step platform for Farmers where information about weather updates, crop prices, shop agri based products, selling their produce, agricultural news are all presented in one mobile application. This is a handy tool for farmers who can now connect and compare prices and availability beforehand.

\section{eMandi app}

The platform does not only facilitate connecting, procuring and selling between the right vendors, but also ensures the right transportation options for the best 
value in the entire transaction1.login with phone number 2.post ad 3.find buyer or seller 4.make a deal

\section{IFFCO-iMandi APP}

IFFCO has partnered with Singapore based technology firm iMandi and launched the app.One stop shop for farmers to buy and sell agri products, allow farmers to buy IFFCO products like fertilizers, seeds at discounted price with free delivery.

\section{Gyandoot project}

In 2000, the State Government in Madhya Pradesh, India, set up a chain of computer kiosks to help provide better access to government information and services in one of its districts - Dhar District.20 kiosks ("soochanalayas") were initially set up in various rural centers, with each kiosk typically serving a population of 20,00030,000 villagers.

Cargrill provide assured marketing outlet without commission and brokerage. It is a private sector initiative aiming to squeeze out market inefficiencies and intermediaries in agriculture marketing. Khadi gramodyog board of Madhya Pradesh and Hindustan Unilever Limited entered into public private partnership. It is a joint venture with umbrella brand 'Vindhya valley'. Milk cooperative society called 'Warna Bazaar' in Kolhapur of Maharashtra has more than 40 outlets running as one stop store for agriculture products. Warana "Wired Village" project was initiated in 1998 by the Prime Minister's Office Information Technology (IT) Task Force .The project aims in fact at giving villagers access to information in local language about crops and agricultural market prices at national, international markets, employment schemes from the government in 70 villages with 150 computers. All the facilitation booths are connected to warana cooperative complex. Warana is a cooperative group including diary, textiles, sugar factory etc.

Mahindra and Mahindra group initiative called Mahindra krishi vihar in madhurai in the year 2000 for providing agriculture extension services and buyers a lot of produce from farmers. Aadhar retail stores by Godrej and Future group in Gujarat and Punjab states who procure directly from farmers for their stores. Other websites like krishivihar.com, agriwatch.com, commodityindia.com also provide market information.

India of uses social media to organize and empower small farmers. Small tea growers in West Bengal India launched a website last year and linked it with Facebook and Twitter to connect growers directly with international buyers. Another example, turmeric farmers in Maharashtra's Sangli district used Facebook's Mobile Messenger to organize themselves and avoid a potentially calamitous price crash due to oversupply. They were able to reach thousands of turmeric farmers.

\section{Uzhavan App}

Tamil Nadu government launched bilingual (Tamil and English) mobile application in a bid to use technology benefit to farmers. It offers 15 key agricultural services to farmers including real time information on crop prices, marketing linkages.

\section{Mandee App}

It is business to business platform for buying the agriculture products by wholesalers, retailers, traders at reasonable prices from farmers in Tamil Nadu.

\section{Napanta App}

Digital agricultural platform to address the inefficiencies in pre harvest management for 
agri produce with superior market linkages across villages in Telengana and Andhra Pradesh. Farmer can access real time information pertaining to daily market prices of 3500+agri markets and 3 year price trend of $300+$ commodities. It is bilingual with Telugu and English.

According to the survey conducted nearly 40 farmers out of 100 use e-NAM app for marketing of farm produce as it is more authentic and user friendly followed by state government apps like in Uzhavan app in Tamil Nadu is used by 38 farmers out of 100 farmers as it is in local language. In Andhra Pradesh and Telengana, NaPanta app is used by 35 farmers out of 100 . The proper adversitment of app is require to make farmers aware of the app available to needy farmers and traders like Mandee app in Tamil Nadu promoted by Vijay Sethupathi.

Smart phones could be a true breakthrough for smallholder farmers where apps are used for agricultural marketing. It creates awareness on the market prices and the demand of the crop produce. Despite all these opportunities, it is worthwhile reinforcing the fact that there is no single best solution for all circumstances. More refined marketing skills will likely recap more benefits than without. Agriculture extension mechanism is becoming dependent on IT to provide appropriate answers to farmers. To encourage digital agripreneurship, companies need to create pool of digitally skilled employees. Young agripreneurs have a key role to play in digitization of agriculture sector. The government and many companies are investing in agriculture marketing solution for welfare of farmers. Digital Agricultural Marketing will play a vital role in the years to come in doubling the farmers produce and tripling the Income of the farmers.

\section{References}

Bibhu Santosh Behera.,Babita Panda., Rudra Ashish Behera., Narayan Nayak.,Anama Charan Beherae S.Jena.(2015). Information Communication Technology Promoting Retail Marketing In Agriculture Sector in India as a Study. International Conference on Intelligent Computing, Communication \& Convergence Procedia Computer Science 48 ( 2015 ) $652-659$

Jairath,M.S., Hema Yadav.2012.Role of ICT in Decision Making in Agricultural Marketing, Ind. Jn. of Agri. Econ. Vol.67, No.3

Ms.Kiruthiga.K,.Dr.Karthi.R,.Ms.Asha.B., Daisy.2015.Agricultural marketing -An overview, International Journal of Scientific and Research Publications, Volume 5, Issue 4, ISSN 2250-3153

Nagendra,V.,2015.Private Sector Initiatives in Agricultural Marketing in India M.S.Ramaiah university of applied sciences publication

Shakeel-Ul-Rehman.,Selvaraj.M.,Syed

Ibrahim.M,.2011.Indian agriculture marketing-An Overview Asian Economic and Social Society. ISSN $(P)$ : 2304-1455/ISSN(E): 2224-4433

Singh,U.S.,Mishra,U.S.,2015.,Marketing

Agricultural Produces Journal of Marketing and Consumer Research ISSN 2422-8451 An International Peerreviewed JournalVol.16, 2015

Singh,U.S.,2011. Marketing Agricultural Produces Journal of Marketing and Consumer Research ISSN 2422-8451 An International Peer-reviewed JournalVol.16, 2015

Sukhpal Singh and Naresh Singla, (2010), Fresh Food Retail Chains in India: Organisation and Impacts, CMA Publication No - 238 
How to cite this article:

Rekha Dabbara, M. Chandrakumar, V. Anandhi and Muruganandhi. D. 2020. Data Driven Marketing Applications for Agriculture Services. Int.J.Curr.Microbiol.App.Sci. 9(02): 29142920. doi: https://doi.org/10.20546/ijcmas.2020.902.331 